\title{
PENERAPAN APLIKASI ANTRIAN PASIEN MENGGUNAKAN METODE WEIGHTED PRODUCT PADA LINGKUNGAN KLINIK
}

\author{
Suryo Adi Wibowo ${ }^{1}$, Yosep Agus Pranoto ${ }^{2}$, Moh. Miftakhur Rokhman ${ }^{3}$, Kartiko Ardi Wibowo ${ }^{4}$ \\ 1,2,3 Teknik Informatika S1 Institut Teknologi Nasional Malang \\ ${ }^{4}$ Teknik Elektro S1 Institut Teknologi Nasional Malang \\ oryusdee@gmail.com
}

\begin{abstract}
ABSTRAK
Pelayanan yang baik merupakan hal yang sangat diinginkan oleh setiap pelanggan (customer) terlebih lagi pada bidang kesehatan. Pada bidang kesehatan, masyarakat sangat menghendaki pelayanan yang cepat dan tepat karena sesungguhnya bidang ini berhubungan langsung dengan keselamatan seseorang. Pelayanan yang lambat dan penanganan yang kurang tepat dapat berakibat fatal sampai meninggalnya seorang pasien. Pasien yang datang ke klinik atau rumah sakit sangat banyak dan beragam tingkat kegawatannya, oleh karena itu pada saat ini pihak klinik atau rumah sakit berlomba - lomba untuk memberikan pelayanan yang baik.

Pemanfaatan teknologi informasi dan komunikasi dapat membantu permasalahan yang terjadi hampir di segala bidang kehidupan. Decision Support System (DSS) merupakan salah satu cabang ilmu pengetahuan pada bidang informatika yang bertujuan untuk mendukung pengambilan keputusan dari beberapa kriteria yang ada. Weight Product (WP) adalah salah satu metode yang ada pada DSS. WP memiliki struktur yang sederhana dan mudah untuk digunakan, karena pada prinsipnya metode ini hanya memberikan bobot pada tiap kriteria kemudian dilanjutkan dengan mengalikannya. Oleh karena itu, dengan menggunakan metode WP ini dapat membantu pihak klinik ataupun rumah sakit dalam menentukan prioritas penanganan pasien secara cepat dan tepat.

Klinik AMC (Ampelgading Medical Center) merupakan salah satu klinik yang berlokasi di Kecamatan Ampelgading, Kabupaten Malang berupaya untuk meningkatkan kualitas dalam memberikan pelayanan terhadap pasien. Salah satu bentuk konkrit yaitu mengikuti pelatihan penggunaan aplikasi menggunakan metode WP untuk menentukan antrian pasien berdasarkan tingkat kegawatannya. Hasil pelatihan menunjukkan bahwa kategori Baik mengalami peningkatan sebesar 45,71\%, kategori Cukup mengalami penurunan sebesar 27,14\% dan kategori Kurang juga mengalami penurunan sebesar $18,57 \%$.
\end{abstract}

Kata kunci : Decision Support System (DSS), Weight Product (WP)

\section{PENDAHULUAN}

\subsection{Analisis Situasi}

Pada bidang kesehatan, pelayan yang cepat dan tindakan yang tepat sangat diharapkan oleh setiap pasien karena berhubungan dengan keselamatan. Proses pelayanan yang lambat dan tindakan medis yang kurang tepat dapat berakibat fatal bahkan sampai kehilangan nyawa pasien. Jumlah pasien yang banyak dengan beragam jenis penyakit dan usia menuntut pihak rumah sakit atau klinik untuk membuat prioritas penanganan pasien secara cepat. Prinsip antrian berdasarkan waktu kedatangan First In First Out (FIFO) kurang sesuai apabila diterapkan untuk penanganan pasien, karena prinsip ini berpedoman pada aturan dimana pasien yang datang terlebih dahulu akan mendapatkan tindakan medis terlebih dahulu. Penentuan antrian pasien pada klinik atau rumah sakit tidaklah mudah karena berdasarkan perhitungan beberapa kriteria yang menentukan tingkat kegawatan pasien dengan proses yang panjang. Kesalahan proses perhitungan menyebabkan kesalahan dalam menentukan prioritas penanganan pasien sehingga dapat menyebabkan hal yang fatal. Pada saat ini penyedia jasa pada bidang kesehatan berlomba - lomba berupa untuk meningkatkan kualitas pelayan terhadap pasien.
Pada saat ini, teknologi informasi dan komunikasi berkembang dengan sangat cepat dan dapat dimanfaatkan untuk membantu menangani permasalahan dalam berbagai bidang kehidupan, khususnya dalam bidang medis. Decision Support System (DSS) merupakan salah satu cabang ilmu pengetahuan pada bidang informatika yang bertujuan untuk mendukung pengambilan keputusan dari beberapa kriteria yang ada. Weight Product (WP) adalah salah satu metode yang ada pada DSS. WP memiliki struktur yang sederhana dan mudah untuk digunakan, karena pada prinsipnya metode ini hanya memberikan bobot pada tiap kriteria kemudian dilanjutkan dengan mengalikannya. Oleh karena itu, dengan menggunakan metode WP ini dapat membantu pihak klinik ataupun rumah sakit dalam menentukan prioritas penanganan pasien secara cepat dan tepat.

Klinik AMC (Ampelgading Medical Center) merupakan salah satu klinik yang berlokasi di Kecamatan Ampelgading, Kabupaten Malang berupaya untuk meningkatkan kualitas dalam memberikan pelayanan terhadap pasien. Salah satu bentuk konkrit yaitu mengikuti pelatihan penggunaan aplikasi menggunakan metode WP untuk menentukan antrian pasien berdasarkan tingkat kegawatannya.

Copyright (c) 2020 Jurnal Mnemonic 


\subsection{Identifikasi dan Perumusan Masalah}

Berdasarka hasil survey awal dan wawancara yang kami lakukan pada obyek studi kasus, mendapatkan beberapa permasalahan utama yaitu:

a. Semakin banyaknya pasien yang datang ke klinik dengan tingkat kegawatan yang beragam sehingga menyebabkan kesulitan dalam menentukan antrian pasien.

b. Dibutuhkannya aplikasi pendataan pasien yang terkait dengan penyakitnya yang membutuhkan penanganan khusus.

c. Dibutuhkannya aplikasi perekaman data pasien yang terkait dengan penyakitnya.

Dibutuhkannya aplikasi yang dapat menentukan antrian pasien berdasarkan tingkat kegawatan, sehingga pasien dengan tingkat kegawatan yang tinggi dapat segera mendapatkan tindakan medis yang akan berimbas pada meningkatnya angka harapan hidup pasien.

\section{LANDASAN TEORI}

\section{2.1 Penelitian Sebelumnya}

Dalam jurnal yang berjudul Implementasi Weight Product Pada Sistem Antrian Pasien Untuk Menunjang Keputusan Prioritas Penanganan Pasien Dengan Tingkat Kegawatan yang ditulis oleh : suryo adi wibowo dan yosep agus pranoto menyatakan bahwa Animo masyarakat terhadap penggunaan layanan kesehatan khususnya layanan BPJS di Kota Malang sangat besar. Data ini dapat dibuktikan bahwa mitra fasilitas kesehatan pratama atau tingkat pertama sejumlah 203 mitra yang terdiri dari 61 puskesmas, 58 dokter praktik, 27 klinik gigi, dan 43 klinik pratama. Seperti keluhan yang sering disampaikan oleh masyarakat pengguna layanan kesehatan (baik pasien umum atau pasien BPJS), yang acapkali berlomba untuk mendapatkan prioritas layanan. Namun keinginan atau kebutuhan mendapatkan prioritas ini secara administratif tidak akan dapat dipenuhi, mengingat adanya otomasi data dari sistem. Pada umumnya otomasi data dari system ini masih menggunakan metode First In First Out (FIFO), pasien yang datang pertama akan mendapatkan layanan pertama. Hal ini dianggap merugikan masyarakat pengguna layanan yang memiliki tingkat urgency yang tinggi, sedangkan jumlah antrian pasien yang semakin membludak. Dalam bidang ICT (Information and Communication Technology), masalah pada sistem antrian dengan tingkat urgency ini dapat diselesaikan dengan teori Decission Support System (DSS).

Pada penelitian ini dirancang sebuah sistem berbasis desktop yang bertujuan untuk menanggulangi masalah antrian yang digunakan untuk mengetahui tingkat kegawatan pasien dapat lebih cepat untuk didahulukan atau diatasi untuk mendapatkan layanan. Sistem ini bekerja dengan memperhatikan beberapa kriterian yang didapatkan dari hasil rekam medis milik pasien. Kriteria itu adalah Tegangan Nadi, Elastisitas Pembuluh Nadi,
Frekwensi Pernafasan / Respiration Rate (RR), serta Suhu atau Temperatur (t). Kemudian sistem melakukan otomasi perhitungan menggunakan metode Weighted Product. Hasilnya, proses sorting descending normalisasi total vektor seluruh pasien pada hari itu, sehingga penentuan prioritas penanganan pasien lebih objektif.

\subsection{Sistem Antrian}

Sistem antrian merupakan sebuah sistem yang berisi aturan untuk menentukan urutan pelanggan dalam menerima pelayanan (Aulele,2014). Terdapat beberapa jenis sistem antrian berdasarkan urutan kedatangan pelanggan yaitu :

1. First In First Out (FIFO) yang berarti bahwa pelanggan yang datang terlebih dahulu akan mendapatkan pelayanan yang pertama.

2. Last In First Out (LIFO) yang berarti bahwa pelanggan yang datang paling akhir akan mendapatkan pelayanan yang pertama.

3. Service In Random Order (SIRO) yang berarti bahwa pelayanan dilakukan secara random atau acak.

4. Priority Service (PRI) yang berarti bahwa pelayanan dilakukan berdasarkan prioritas (Purnawan, Dedy DKK, 2013).

\subsection{Metode Weighted Product}

Weight Product (WP) merupakan salah satu metode pada DSS yang sederhana dan mudah untuk digunakan. Rumus metode WP ditunjukkan pada persamaan 1 .

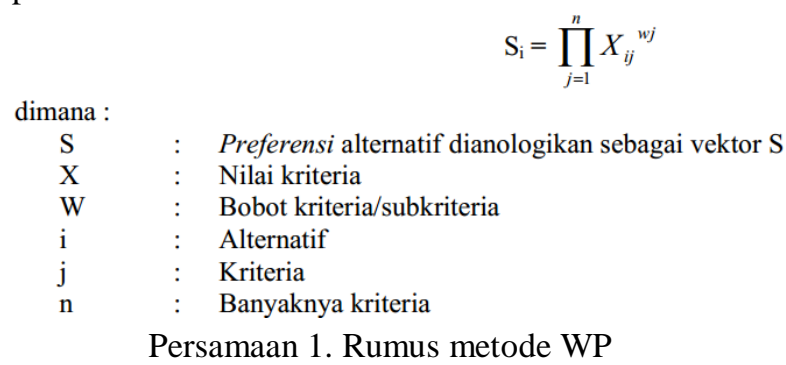

Metode ini menggunakan hasil perkalian penilaian atribut dan masih harus melalui proses dimana dibandingkan dengan nilai standart. Bobot pada atribut memiliki fungsi sebagai pangkat pada proses perkalian dan dapat bernilai positif maupun negatif (Agustin, 2017).

\subsection{Gambaran IPTEK ditawarkan}

Untuk mengatasi permasalahan yang terjadi pada obyek studi kasus, maka dibuat aplikasi yang dapat mempercepat penentuan prioritas penanganan pasien. Aplikasi yang dibuat memiliki 3 form yaitu Setting bobot kriteria, Input data pasien dan Proses antrian pasien. Pada form Setting bobot kriteria digunakan untuk memberikan bobot kriteria yang akan digunakan pada proses perhitungan dengan menggunakan metode WP (Weighted Product). Kriteria yang digunakan untuk menentukan 
kegawatan Pasien yaitu Tekanan Darah (TD), Detak Jantung (HR), Detak nadi (N), Korelasi HR dan N, Tegangan Nadi, Elastisitas Pembuluh Nadi, Frekwensi Pernafasan (RR) dan Suhu Badan (T). Setting bobot dilakukan secara manual oleh petugas dengan mengacu tenaga ahli dalam hal ini adalah Dokter.

\section{METODE PELAKSANAAN}

\subsection{Metode yang Digunakan}

Metode yang digunakan untuk menentukan prioritas penanganan pasien pada aplikasi ini adalah Weighted Product (WP). Metode ini merupakan salah satu metode penyelesaian masalah MADM (Multi Attribute Decision Making). Metode ini memiliki proses yang relatif sederhana dan mudah untuk digunakan sehingga sangat cocok diaplikasikan pada bahasa pemrograman.

\subsection{Tempat dan Waktu Pengabdian}

Mitra yang kami beri pelatihan adalah sebuah Klinik AMC (Ampelgading Medical Center) yang terletak di Desa Tirtomarto, Kecamatan Ampelgading, Kabupaten Malang. Pada klinik ini banyak pasien yang datang berobat dengan berbagai macam tingkat kegawatan. Oleh sebab itu, perlu diberikan pelatihan kepada tenaga medis mengenai penggunaan aplikasi untuk menentukan prioritas penanganan pasien berdasarkan tingkat kegawatannya sehingga proses pelayanan bisa lebih cepat dan tepat.

\subsection{Kerangka konsep penyelesaian masalah}

Kerangka konsep penyelesaian masalah ditunjukkan pada Gambar 1 :

\subsection{Rancangan Evaluasi}

Untuk menguji sistem yang telah dirancang dilakukan tahap pengujian.

1. Uji fungsional sub sistem

Pada pengujian ini setiap komponen diuji apakah berfungsi atau tidak

2. Pengujian secara keseluruhan

Pada pengujian ini ,sistem akan diuji dan dievaluasi secara keseluruhan. Apakah telah sesuai dengan studi kasus yang ada dilapangan dengan melibatkan seorang pakar.sedangkan evaluasi perancangan kebutuhan fungsional dilakukan dengan cara melakukan pengujian fungsionalitas agar mengetahui kinerja sistem dan apakah metode yang digunakan telah sesuai atau tidak.

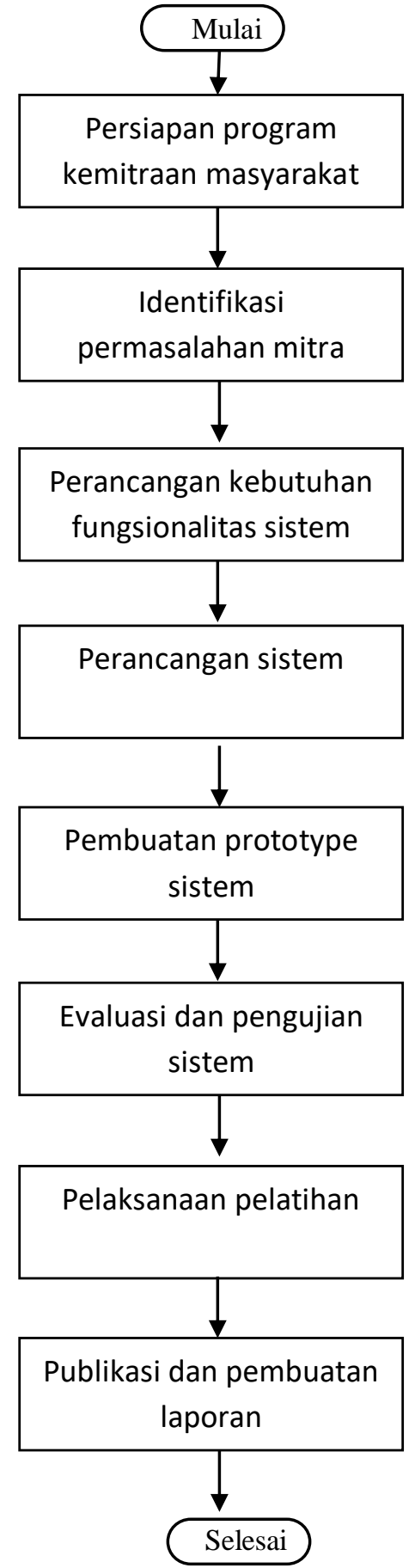

Gambar 2. Kerangka konsep penyelesaian masalah 
4. Pelaksanaan Pengabdian Masyarakat 4.1 Kondisi lingkungan Lokasi Pengabdian Masyarakat

Berikut merupakan dokumentasi dari kegiatan Pengabdian Masyarakat lokasi gambaran kondisi lingkungan pada seperti di tunjukkan pada Gambar 3 dan Gambar 4.

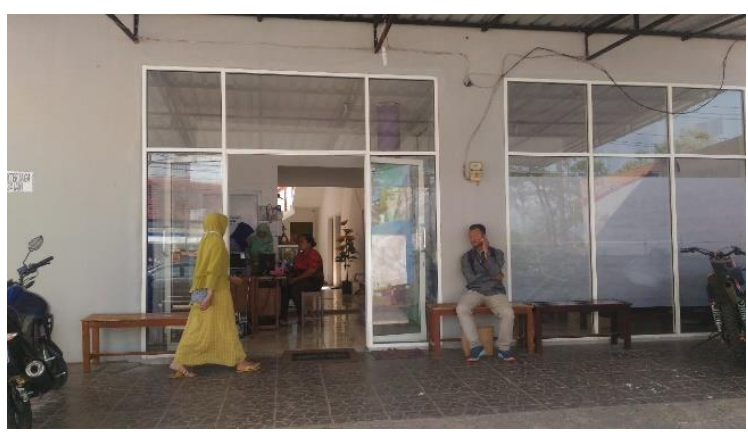

Gambar 3. Lokasi Pengabdian Masyarakat

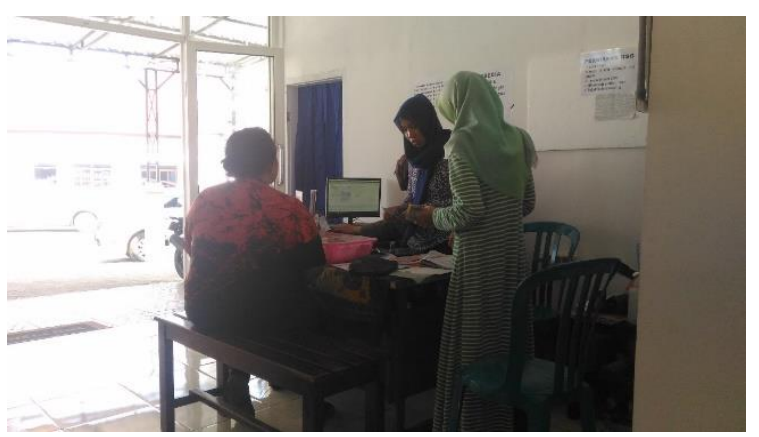

Gambar 4 Kondisi lingkungan Lokasi Pengabdian Masyarakat

Berikut merupakan dokumentasi dari kegiatan Pengabdian Masyarakat berupa produk seperti di tunjukkan pada Gambar 5 dan Gambar 6.

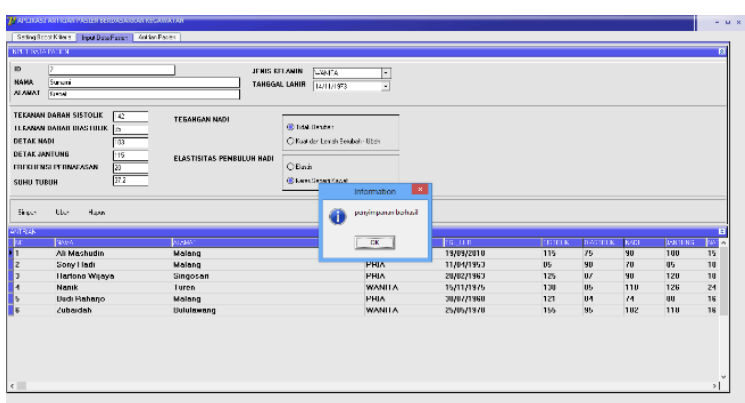

Gambar 5 Form Input Data Pasien
Form Input Data Pasien digunakan untuk melakukan pendataan identitas pasien dan data kriteria kegawatan pasien. Identitas pasien meliputi ID pasien, Nama, Alamat, Jenis Kelamin dan Tanggal Lahir Pasien. Form Input Data Pasien ditunjukkan pada Gambar 6

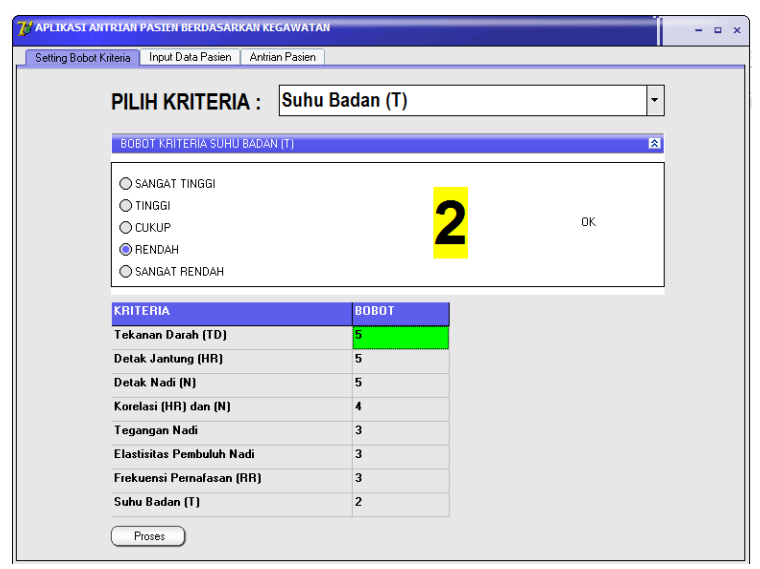

Gambar 6 Form Setting Bobot Kriteria

Form Proses Antrian Pasien digunakan untuk menampilkan hasil antrian pasien ditunjukkan pada Gambar 7

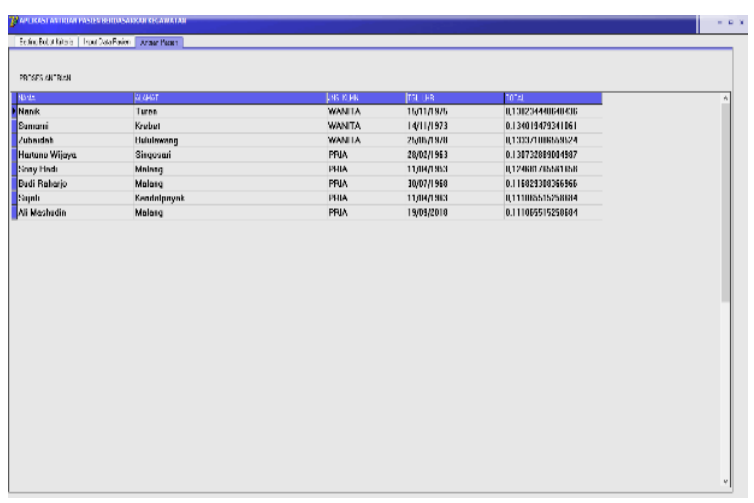

Gambar 7. Form Hasil Antrian Pasien

\subsection{Hasil pengujian sebelum dilakukan Pelatihan}

Pada saat sebelum dilakukan proses pelatihan dilakukanlah wawancara yang melibatkan 10 orang tenaga medis sebagai responden. Berdasarkan proses wawancara didapatkan hasil sesuai dengan Tabel 1 sebagai berikut. 
Tabel 1. Hasil Pengujian Sebelum Dilakukan Implementasi

\begin{tabular}{|c|c|c|c|c|}
\hline & \multirow{2}{*}{ Pertanyaan } & \multicolumn{3}{|c|}{ Penilaian } \\
\hline & & $\mathrm{B}$ & $\mathrm{C}$ & $\mathrm{K}$ \\
\hline 1 & $\begin{array}{l}\text { Apakah tenaga kesehatan } \\
\text { dapat menggunakan komputer }\end{array}$ & 5 & 5 & 0 \\
\hline 2 & $\begin{array}{l}\text { Apakah tenaga kesehatan } \\
\text { dapat membedakan pasien } \\
\text { lama dan pasien baru? }\end{array}$ & 1 & 6 & 3 \\
\hline 3 & $\begin{array}{l}\text { Apakah tenaga kesehatan } \\
\text { dapat melihat riwayat } \\
\text { penyakit pasien lama? }\end{array}$ & 0 & 6 & 4 \\
\hline 4 & $\begin{array}{l}\text { Apakah tenaga kesehatan } \\
\text { dapat membuat keputusan } \\
\text { kegawatan pasien? }\end{array}$ & 7 & 3 & 0 \\
\hline 5 & $\begin{array}{l}\text { Apakah tenaga kesehatan } \\
\text { selalu tepat dalam } \\
\text { menentukan tingkat } \\
\text { kegawatan pasien utnuk } \\
\text { menentukan antrian? }\end{array}$ & 7 & 3 & 0 \\
\hline 6 & $\begin{array}{l}\text { Apakah tenaga kesehatan } \\
\text { memiliki perangkat bantu } \\
\text { untuk menentukan tingkat } \\
\text { kegawatan pasien? }\end{array}$ & 0 & 0 & 10 \\
\hline 7 & $\begin{array}{l}\text { Apakah tenaga kesehatan } \\
\text { cukup konsisten dalam } \\
\text { menentukan kondisi } \\
\text { kegawatdaruratan pasien } \\
\text { sebagai acuan untuk } \\
\text { menentukan antrian? }\end{array}$ & 7 & 3 & 0 \\
\hline 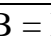 & $\mathrm{C}=$ Cukup & & & \\
\hline
\end{tabular}

Baik $=27 \quad$ Cukup $=26 \quad$ Kurang $=17$

Berdasarkan rekapan hasil wawancara pada Tabel 1, diperoleh prosentase Baik sebesar 38,57 \%, prosentase Cukup sebesar $37,14 \%$ dan prosentase Kurang sebesar 24,28\%

\subsection{Hasil pengujian setelah dilakukan \\ Pelatihan}

Tabel 2 menunjukkan hasil proses wawancara setelah dilakukan pelatihan, dengan melibatkan 10 orang yang sama sebagai responden. Berdasarkan rekapan hasil wawancara pada Tabel2, diperoleh jumlah kategori Baik = 59 atau 84,28\%, Cukup = 7 atau $10 \%$ dan Kurang $=4$ atau 5,71\%.

Perbedaan kategori Baik setelah dan sebelum dilakukan pelatihan menggunakan aplikasi adalah $84,28 \%-38,57 \%=45,71 \%$. Perbedaan kategori Cukup sebelum dan setelah dilakukan pelatihan yaitu $37,14 \%-10 \%=27,14 \%$. Perbedaan kategori kurang sebelum dan setelah dilakukan pelatihan yaitu $24,28 \%-5,71 \%=18,57 \%$.
Tabel 2. Hasil Pengujian Setelah Dilakukan Pelatihan

\begin{tabular}{|c|c|c|c|c|}
\hline & \multirow{2}{*}{ Pertanyaan } & \multicolumn{3}{|c|}{ Penilaian } \\
\hline & & B & $\mathrm{C}$ & K \\
\hline 1 & $\begin{array}{l}\text { Apakah tenaga kesehatan } \\
\text { dapat menggunakan } \\
\text { komputer }\end{array}$ & 8 & 2 & 0 \\
\hline 2 & $\begin{array}{l}\text { Apakahtenaga kesehatan } \\
\text { dapat membedakan pasien } \\
\text { lama dan pasien baru? }\end{array}$ & 10 & 0 & 1 \\
\hline 3 & $\begin{array}{l}\text { Apakah tenaga kesehatan } \\
\text { dapat melihat riwayat } \\
\text { penyakit pasien lama? }\end{array}$ & 5 & 0 & 0 \\
\hline 4 & $\begin{array}{l}\text { Apakah tenaga kesehatan } \\
\text { dapat membuat keputusan } \\
\text { kegawatan pasien? }\end{array}$ & 6 & 0 & 1 \\
\hline 5 & $\begin{array}{l}\text { Apakah tenaga kesehatan } \\
\text { selalu tepat dalam } \\
\text { menentukan tingkat } \\
\text { kegawatan pasien utnuk } \\
\text { menentukan antrian? }\end{array}$ & 7 & 3 & 0 \\
\hline 6 & $\begin{array}{l}\text { Apakah tenaga kesehatan } \\
\text { memiliki perangkat bantu } \\
\text { untuk menentukan tingkat } \\
\text { kegawatan pasien? }\end{array}$ & 6 & 0 & 0 \\
\hline 7 & $\begin{array}{l}\text { Apakah tenaga kesehatan } \\
\text { cukup konsisten dalam } \\
\text { menentukan kondisi } \\
\text { kegawatdaruratan pasien } \\
\text { sebagai acuan untuk } \\
\text { menentukan antrian? }\end{array}$ & 17 & 2 & 2 \\
\hline
\end{tabular}

\section{Kesimpulan Dan Saran \\ 5.1 Kesimpulan}

Berdasarkan hasil pelatihan penerapan aplikasi antrian pasien menggunakan metode weighted product pada lingkungan klinik diperoleh kesimpulan bahwa dapat meningkatkan ketepatan tenaga medis dalam menentukan tingkat kegawatan pasien. Hal ini dapat dibuktikan dari hasil kuisioner yang diberikan kepada tenaga medis sebelum dan sesudah melakukan pelatihan. Hasil menunjukkan bahwa kategori Baik mengalami peningkatan sebesar $45,71 \%$, kategori Cukup mengalami penurunan sebesar 27,14\% dan kategori Kurang juga mengalami penurunan sebesar $18,57 \%$.

\subsection{Saran}

Saran yang dapat diberikan agar dapat lebih meningkatkan hasil pelatihan yaitu :

1. Memperpanjang durasi waktu pelatihan.

2. Memperbanyak tenaga pelatih.

3. Mengembangkan aplikasi ke dalam bentuk mobile.

4. Mengembangkan metode Weighted Product menjadi metode Triase dalam menentukan kegawatan pasien. 


\section{DAFTAR PUSTAKA}

[1] Agustin, Yoga Handoko, and Hendra Kurniawan. "Sistem Pendukung Keputusan Penilaian Kinerja Dosen Menggunakan Metode Weighted Product (Studi Kasus: STMIK Pontianak)." Seminar Nasional Informatika (SNIf). Vol. 1. No. 1. 2017.

[2] Aulele, Salmon N. "Analisis Sistem Antrian Pada Bank Mandiri Cabang Ambon." BAREKENG: JURNAL ILMU MATEMATIKA DAN TERAPAN 8.1 (2014): 45-49.

[3] Purnawan, Dedy. "Analisis Model Antrian Perbaikan Sepeda Motor Dengan Menggunakan Program Visual Basic".UNNES Journal of Matematics 2.1 (2013) : $39-45$.

[4] Wibowo, Suryo Adi dan Pranoto, Yosep Agus. "Implementasi Weight Product Pada Sistem Antrian Pasien Untuk Menunjang Keputusan Prioritas Penanganan Pasien dengan Tingkat Kegawatan”. Jurnal MNEMONIC 2.2 (2018) : $42-49$ 